\title{
NEW HOST, GEOGRAPHICAL RECORDS, AND SOME ECOLOGICAL ASPECT OF ABSONIFIBULA BYCHOWSKYI LAWLER ET OVERSTREET, 1976 (MONOGENEA: DICLIDOPHORIDAE) FROM ESTUARINE AREAS OF ARGENTINA
}

\author{
Sergio R. MARTORELLI ${ }^{1,2}$, Norma H. SARDELLA ${ }^{1,3}$, and Paula S. MARCOTEGUI ${ }^{1,2}$ \\ ${ }^{1}$ Consejo Nacional de Investigaciones Cientificas y Técnicas, Argentina \\ ${ }^{2}$ Centro de Estudios Parasitológicos y Vectores, Universidad Nacional de La Plata, La Plata, Argentina \\ ${ }^{3}$ Departamento de Biología, Facultad de Ciencias Exactas y Naturales, Universidad Nacional de Mar del Plata, \\ Funes, Mar del Plata, Argentina
}

\begin{abstract}
Martorelli S.R., Sardella N.H., Marcotegui P.S. 2007. New host, geographical records, and some ecological aspect of Absonifibula bychowskyi Lawler et Overstreet, 1976 (Monogenea: Diclidophoridae) from estuarine areas of Argentina. Acta Ichthyol. Piscat. 37 (1): 1-6.
\end{abstract}

\begin{abstract}
Background. Monogenean parasites from mixohaline areas of the South Atlantic coast of Argentina are very poorly reported. The aim of this paper is report a new host and locality for Absonifibula bychowskyi, a monogenean confined to fish living in estuarine areas. Some ecological considerations about the host-parasite relationship are also discussed. Materials and Methods. Parasites collected from whitemouth croaker, Micropogonias furnieri (Desmarest, 1823) (Actinopterygii: Sciaenidae), were studied from fixed- and live specimens, with standard procedures used in parasitology. Prevalence, mean intensity, and abundance of parasites were calculated and related to the host body size. Spearman's rank correlation coefficient was calculated to determine possible correlations between host length, parasite intensity, and prevalence.

Results. Absonifibula bychowskyi (Monogenea: Diclidophoridae) Lawler et Overstreet, 1976 is reported for the first time from the gills of whitemouth croaker, at the Samborombón Bay, a mixohaline area in the Buenos Aires Province, Southwest Atlantic Ocean. The parasite was found only in juveniles of M. furnieri that use the Samborombón Bay as the main estuarine nursery ground area. When the croaker migrated seawards, A. bychowskyi disappeared from the gills may be related to the increased salinity.

Conclusions. This is the first record for Absonifibula bychowskyi in the Southwest Atlantic and M. furnieri. (It constitutes a new host record.) The presence of A. bychowskyi in M. furnieri could be indicative of the origin of the fish.
\end{abstract}

Keywords: Absonifibula, Monogenea, Southern Atlantic, Micropogonias furnieri, Diclidophoridae, fish parasites

\section{INTRODUCTION}

The whitemouth croaker, Micropogonias furnieri (Desmarest, 1823) (Actinopterygii: Sciaenidae), a euryhaline, sublittoral, demersal fish, living on muddy- and sandy bottoms of the littoral zone with a preference for estuarine regions, is one of the most valuable coastal fish species of Argentina (Carozza et al. 2004). This sciaenid is distributed from the Yucatán Península to San Matías Gulf (Isaac-Nahum 1988). Concentrations of the spawning adults have been observed in the Rio de La Plata estuary, a region with low salinity. Juveniles may be found all year round in the Rio de La Plata and in the Samborombón Bay (López and Castelo 1968); this bay is an important nursery ground for croaker, where juveniles live up to the age of 2-3 years (Acha et al. 2001, Carozza et al. 2004). Following the first feeding period the juveniles migrate seawards and adult returns later to the estuaries to spawn. Sánchez et al. (1991), studying croaker nutrition in the Samborombón Bay, stated that juveniles of M. furnieri are distributed in three groups: below $14 \mathrm{~cm}$, from 14 to $22 \mathrm{~cm}$, and above $22 \mathrm{~cm}$ (total length). The presence of marine organisms in the stomach contents of fish exceeding $22 \mathrm{~cm}$ (total length) indicates the beginning of the seaward migration.

In a previous study, on the helminth communities of M. furnieri, an unidentified monogenean in the gills of juvenile croakers smaller than $25 \mathrm{~cm}$ (total length) was found (Sardella et al. 1985). The aim of the present paper is to report the presence of Absonifibula bychowskyi Lawler et Overstreet, 1976 (Monogenea: Diclidophoridae) in juveniles of $M$. furnieri and to discuss some ecological aspects of the relationships of the parasites with their host and with the environment.

\footnotetext{
* Correspondence: Dr. Sergio R. Martorelli, Centro de Estudios Parasitológicos y Vectores, Universidad Nacional de La Plata, calle 2 Nro. 584 (1900), La Plata, Argentina, phone: 54-221-4233471, fax: 54-221-4232327, e-mail: sergio@cepave.edu.ar
} 


\section{MATERIALS AND METHODS}

The study is based on gill examination of 270 specimens of Micropogonias furnieri from 4 to $25 \mathrm{~cm}$ total length. Whitemouth croakers were collected by trawl in the Samborombón Bay (lat $35^{\circ} 30^{\prime} \mathrm{S}-36^{\circ} 20^{\prime} \mathrm{S}$, long $56^{\circ} 43^{\prime} \mathrm{W}-57^{\circ} 30^{\prime} \mathrm{W}$ ) (106 individuals in 1987, 41 in 1988, and 123 in 1997). This fish were fixed in buffered $10 \%$ formalin and transported to the laboratory where they were dissected and examined under a stereoscopic microscope. Other specimens collected in the Samborombón Bay and Mar Chiquita Lagoon $\left(37^{\circ} 46^{\prime} \mathrm{S}, 57^{\circ} 27^{\prime} \mathrm{W}\right.$ ) from 2001 to 2005 , and 20 fish of 5 to $10 \mathrm{~cm}$ total length collected in coastal areas of Mar del Plata $\left(38^{\circ} 30^{\prime} \mathrm{S}-36^{\circ} 20^{\prime} \mathrm{W}\right)$ were also examined for monogeneans. This live fish were transported to the laboratory in plastic containers with brackish water, and kept alive until examined. The fish were measured (total length), the gills were dissected, and the monogeneans were removed from the gills with the aid of needles. These specimens were used only for morphological studies and not included in the quantitative data. Live parasites were fixed under slight pressure of the cover glass in AFA fixative (alcohol, formaldehyde, acetic acid) and stored in 70\% alcohol. Monogeneans recovered from the formalin-fixed fish where also stored in $70 \%$ alcohol. All specimens where stained with chloride carmine or Van Cleave's haematoxylin and mounted in Canada balsam. Measurements of monogeneans were made with an ocular micrometer and are in millimetres, unless otherwise indicated. The number of specimens measured is given in parentheses and followed by the mean and the range. Figures were made with the aid of a drawing tube. Prevalence, mean intensity, and abundance of parasites were calculated and related to host body size (divided into 8 size classes) following Bush et al. (1997). Spearman's rank correlation coefficient was calculated to determine possible correlations between host length, parasite intensity, and prevalence (Morales and Pino 1987).

\section{RESULTS}

Absonifibula bychowskyi Lawler et Overstreet, 1976 (Figs. 1-6).

The specimens collected from Micropogonias furnieri were compared with the original description (Lawler and Overstreet 1976) and with voucher specimens borrowed from the parasitological collection at the Parasitological Laboratory (Gulf Cost Research Laboratory, University of Southern Mississippi). The morphology of our specimens is consistent with the original description and with the main features of the genus Absonifibula Lawler et Overstreet, 1976 characterized by: absent eyespot, haptor with four pairs of pedunculate clamps, similar in shape but different in size, clamps bivalved with membrane present, pretesticular, convoluted ovary with mature portion directed posteriorly, vagina present, and genital atrium armed with three pairs of spines. The main measurements are presented and compared in Tables 2 and 3 . We concluded that the monogenean, described in the present study, collected from M. furnieri, was similar in all morphological features with the specimens of $A$. bychowskyi from M. undulatus from the region of the Mississippi Sound, Gulf of Mexico.

\section{Taxonomic Summary}

Host: Micropogonias furnieri.

Location: gills.

Locality: the Samborombón Bay (lat $35^{\circ} 30^{\prime} \mathrm{S}-36^{\circ} 20^{\prime} \mathrm{S}$, long $\left.56^{\circ} 43^{\prime} \mathrm{W}-57^{\circ} 30^{\prime} \mathrm{W}\right)$.

Number of specimens studied: 20 measurements taken on 5-20 specimens.

Voucher specimens: Deposited at the Helminthological Collection of the La Plata Museum. Collection number: 5572.

\section{Ecological aspects}

All specimens of Absonifibula bychowskyi were found in juveniles of Micropogonias furnieri collected from the estuarine areas of Buenos Aires province, Argentina; 90.2\% of monogeneans were recovered from fish up to $12 \mathrm{~cm}$ in length, with prevalence, intensity and abundance, $10.37 \%$, 2.18 , and 0.22 , respectively. The higher values of prevalence and intensity were confirmed in croakers from 5 to $10 \mathrm{~cm}$ in length. No fish larger than $22 \mathrm{~cm}$ was found parasitized with $A$. bychowskyi.

No significant differences of intensity $(r=-0.03, P>0.05)$ and prevalence $(r=0.12, P>0.05)$, in relation to fish length, among juvenile fish size classes, were found (Table 1).

The majority of the monogeneans were recovered from gill arches I and II (Arch I: 50 (81.97\%); Arch II: 9 (14.75\%); Arch III: 1 (1.64\%), and Arch IV: 1 (1.64\%). Each worm was attached to three gill filaments, with the last three pairs of clamps, using two adjacent filaments. The larger first pair of clamps was attached, tandemly around the third filament in an adjacent hemibranch.

\section{DISCUSSION}

Absonifibula bychowskyi was originally described by Lawler and Overstreet (1976) from Atlantic croaker, Micropogon (=Micropogonias) undulatus, from the Mississippi Sound, Gulf of Mexico. Later, Thoney $(1991,1993)$ recorded it from the same host at the Chesapeake Bay and the Palmico Sound, North Carolina.

The presence of $A$. bychowskyi in M. furnieri from mixohaline Argentinean waters could be indicative of the origin of the fish. All infections of this monogenean in croakers, examined in the presently reported study, were confirmed for juveniles of $M$. furnieri living inside the estuaries. This finding is consistent with the results obtained for $A$. bychowskyi in M. undulatus, inhabiting Ocean Spring areas, Mississippi (Lawler and Overstreet 1976). However, the mean prevalence in juvenile Argentine croakers was higher and mean intensity was lower than those reported by Lawler and Overstreet (1976), possibly due to environmental differences of temperature and salinity between the two areas.

Young croakers use the Samborombón Bay as a main nursery ground throughout the year (López and Castelo 1968, Acha et al. 2001, Carozza et al. 2004). This host behaviour also occurs in M. undulatus in Mississippi (Lawler and Overstreet 1976) and in M. furnieri in other latitudes. In this sense, Vazzoler (1991) and Alves and Luque (2001) communicated that juveniles of croaker from Brazilian coasts also migrate from estuarine to marine areas. 


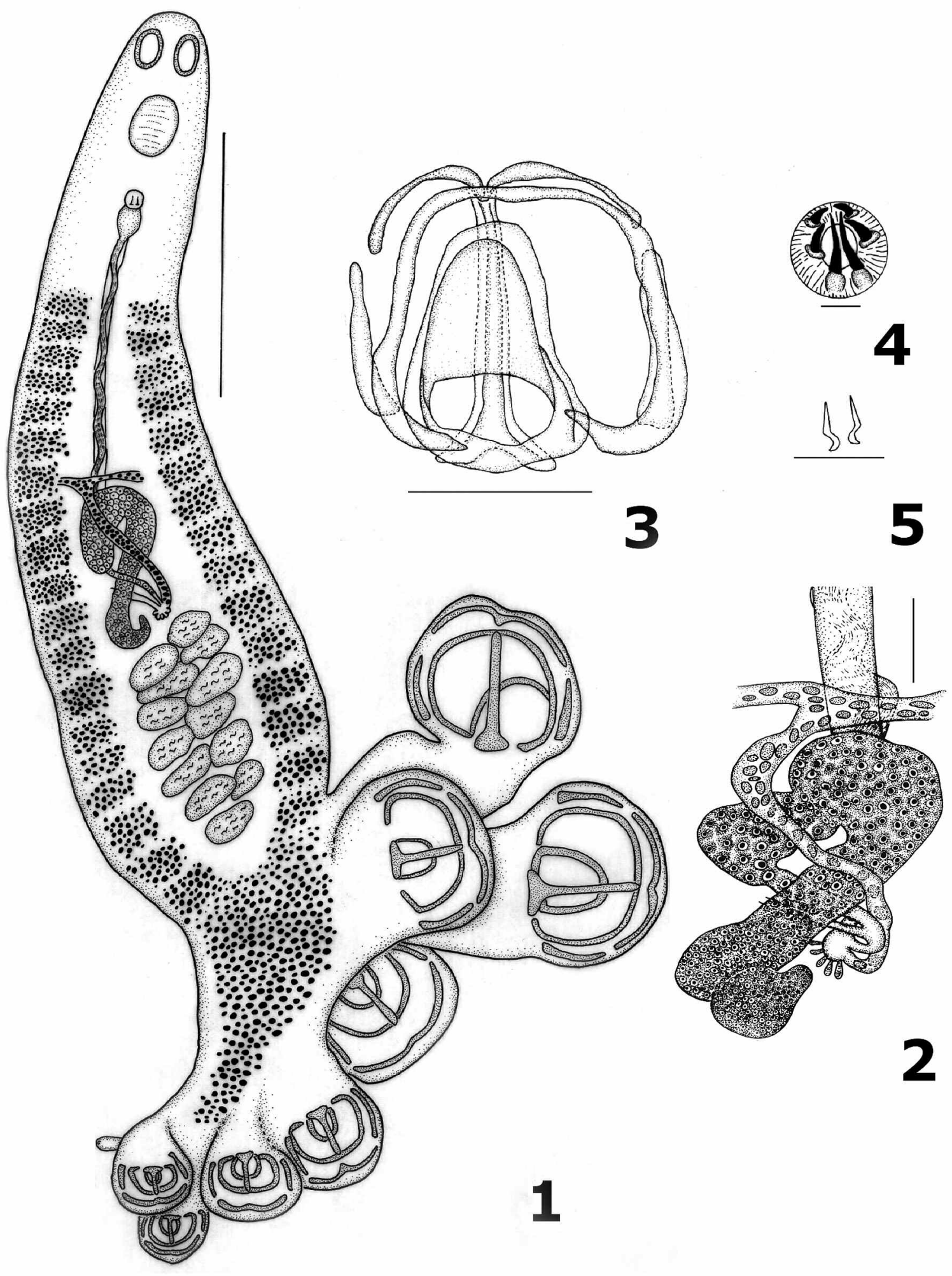

Figs. 1-5. Absonifibula bychowskyi Lawler et Overstreet, 1976; Fig. 1. Whole-mount, ventro-lateral; Scale-bar $=0.5 \mathrm{~mm}$; Fig. 2. Female genitalia, ventral view; Scale bar $=0.05 \mathrm{~mm}$; Fig. 3. Clamp of voucher specimen; Scale-bar $=0.1 \mathrm{~mm} ;$ Fig. 4. Genital atrium; Scale-bar $=0.01 \mathrm{~mm}$; Fig. 5. Lappet anchors; Scale-bar $=0.005 \mathrm{~mm}$ 
Prevalence, intensity, and abundance of Absonifibula bychowskyi in different size

Table 1 classes of juveniles of Micropogonias furnieri from the Samborombón Bay

\begin{tabular}{lrrrrrr}
\hline $\begin{array}{l}\text { Fish length classes } \\
{[\mathrm{cm}]}\end{array}$ & NHE & NHP & NP & P $(\%)$ & MI & A \\
\hline $3.5-5$ & 27 & 1 & 1 & 3.7 & 1 & 0.04 \\
$5.1-7.5$ & 74 & 9 & 20 & 12.16 & 2.22 & 0.27 \\
$7.6-10$ & 62 & 11 & 27 & 17.74 & 2.45 & 0.43 \\
$10.1-12.5$ & 34 & 2 & 7 & 5.88 & 3.5 & 0.2 \\
$12.6-15$ & 30 & 1 & 2 & 3.33 & 2 & 0.06 \\
$15.1-17.5$ & 18 & 0 & 0 & 0 & 0 & 0 \\
$17.6-20$ & 8 & 1 & 1 & 12.50 & 1 & 0.12 \\
$20.1-25$ & 17 & 3 & 3 & 17.64 & 1 & 0.18 \\
Total & 270 & 28 & 61 & 10.37 & 2.18 & 0.22 \\
\hline
\end{tabular}

NHE, number of hosts examined; NHP, number of hosts parasitized;

$\mathrm{NP}$, number of parasites; P, prevalence; MI, mean intensity; A, abundance.

A comparison of measurements (in $\mu \mathrm{m}$ ) of Absonifibula bychowskyi

Table 2 from Micropogonias undulaus (Gulf of Mexico) and M. furnieri (Argentina)

\begin{tabular}{lcc}
\hline Measurement & Present study & Lawler and Overstreet (1976) \\
\hline Total body length & $1780(1220-2140)$ & $2490(1990-3040)$ \\
Total body width & $340(260-440)$ & $551(363-783)$ \\
Oral sucker length & $58(45-85)$ & $60(46-67)$ \\
Oral sucker width & $55(35-70)$ & $48(38-58)$ \\
Pharynx length & $101(80-115)$ & $103(84-131)$ \\
Pharynx width & $86(70-115)$ & $74(58-96)$ \\
Genital atrium diameter & $32(26-37)$ & $33(29-38)$ \\
Haptor length & $462(220-720)$ & $631(477-840)$ \\
Eggs length (with filament) & $327(290-369)$ & $311(203-429)$ \\
Eggs width & $47(39-56)$ & $51(41-58)$ \\
\hline
\end{tabular}

A comparison of clamp dimensions (in $\mu \mathrm{m}$ ) of Absonifibula bychowskyi from Micropogonias undulatus (Gulf of Mexico) and M. furnieri (Argentina)

\begin{tabular}{lcccc}
\hline & \multicolumn{2}{c}{ Present study } & \multicolumn{2}{c}{ Lawler and Overstreet (1976) } \\
\cline { 2 - 5 } & Length & Width & Length & Width \\
\hline First clamp & $239(180-290)$ & $275(240-340)$ & $206(171-241)$ & $233(206-267)$ \\
Second clamp & $165(130-220)$ & $190(160-260)$ & $147(110-197)$ & $176(139-209)$ \\
Third clamp & $148(130-170)$ & $173(140-221)$ & $129(93-148)$ & $150(119-171)$ \\
Fourth clamp & $89(60-140)$ & $102(60-140)$ & $84(67-99)$ & $99(81-122)$ \\
\hline
\end{tabular}

Table 3 


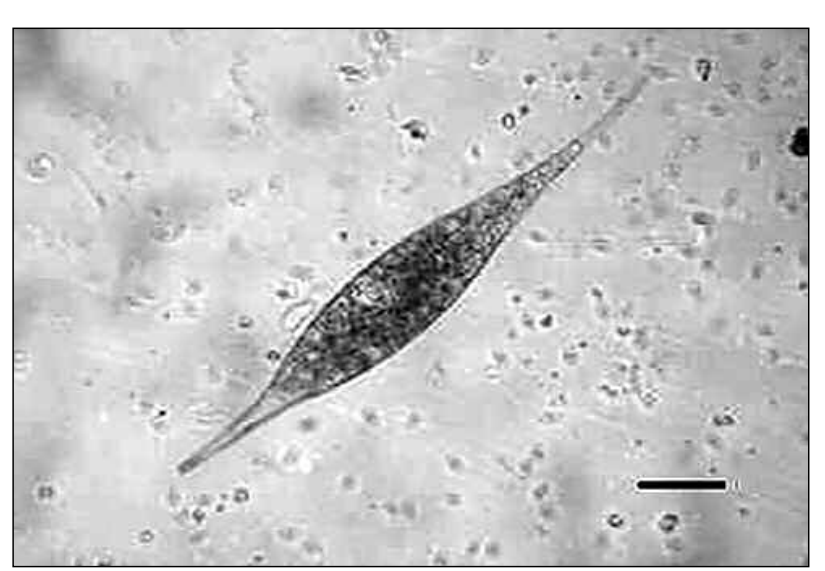

Fig. 6. Absonifibula bychowskyi Lawler et Overstreet, 1976; Micrograph of in vivo extrauterine egg; Scale-bar $=0.06 \mathrm{~mm}$

As stated by Sánchez et al. (1991), croakers larger than $22 \mathrm{~cm}$ length start to migrate seawards. During this research only two juvenile fishes, of $10 \mathrm{~cm}$ of total length, were found parasitized with $A$. bychowskyi in sea waters but very close to an estuarine area of Mar Chiquita coastal lagoon. In fishes greater than $22 \mathrm{~cm} \mathrm{~A}$. bychowskyi was not found, but two other monogeneans, Neomacrovalvitrema argentinensis Suriano, 1975 and Neopterinotrematoides avaginata Suriano, 1975, are common gill parasites of adult whitemouth croaker (Sardella et al. 1985). The lack of A. bychowskyi in older fish may be related to the increased salinity when $M$. furnieri migrates to the sea. The fish return annually to the estuary to spawn where juvenile fishes occupy the mixohaline waters (López and Castelo 1968, Lawler and Overstreet 1976, Isaac-Nahum 1988, Alves and Luque 1999, 2001, Acha et al. 2001, Carozza et al. 2004). Lawler and Overstreet (1976) postulated that the higher prevalence of worms in young fish could be due to differences in biochemistry with fish age or to differences in population density. Young croakers are more densely concentrated inside the estuaries, facilitating transmission of the worms among hosts. Angelescu and Prenski (1987) stated that adult hake progressively lose the filtration capacity of the first branchial arch, an important function for the retention of parasite larvae. A similar situation may be operating in A. bychowskyi in croaker. Shotter (1973), Etchegoin and Sardella (1990), and Timi and Lanfranchi (2006) suggested that the decrease in the number of parasites in gills is attributable to an increase in the strength of the respiratory current in older fish.

With respect to microhabitat selections the monogeneans studied here, by their preference for gill arches I and II, showed a transverse partitioning according with Rohde (1993). In relation to the location of the monogenean on the gill arches there have been many reports in the last 40 years. Rohde and Roubal (1981) found in only one specimen of Acanthocybium solandri forty-seven specimens of Neothoracocotyle acanthocybii (Monogenea: Gastrocotylidae) with most of all on the first and second gill arches. Oliva and Luke (1998) report a clear preference by a gill arch and a sector of the gill in the monogenean Microcotyle nemadactylus, a parasite of Cheilodactylus variegatus from Peru. Gutierrez and Martorelli (1999a), studying five Monogenea species on the gills of a catfish, Pimelodus macula$t u s$, in the Río de la Plata (Argentina), found that congeneric species had a generic-specific preference for certain gillhemibranchs. Finally, in the family Diclidophoridae, Frankland (1955) and Llewellyn (1956) reported, for example, the preference by different gill arches in Diclidophora species parasites of Gadus spp. The cause for these differences in gill arch preference are not yet clear and have been linked to two hypotheses: differences in water current over the gills surface (Suydam 1971, Arme and Halton 1972, Hanek and Fernando 1978, Gutiérrez and Martorelli 1994), or the greater area of certain gills that allows more parasites to attach to these arches (Adams 1986, Buchmann 1989, Koskivaara et al. 1992). In relation with this subject, Gutierrez and Martorelli (1999 b) — who used two computer simulation programs, based on gill area and water current, to generate parasite metapopulations with clumped patterns, and comparing the results with true distributions of selected freshwater monogenean - concluded that both the gill area and the water current, determined the preference by the gill arches in freshwater monogenean parasites of catfish.

In relation to the geographical distribution of Absonifibula bychowskyi, this is the first finding of this parasite from the Southwest Atlantic and from M. furnieri and it constitutes a new host record. Despite the broad distribution of the whitemouth croaker in the Atlantic Ocean, Alves and Luque (1999) did not find A. bychowskyi in juveniles of M. furnieri $(10-25 \mathrm{~cm})$ captured from the State of Rio de Janeiro (Brazil). The presence of this disrupted distribution of $A$. bychowskyi in separate estuarine areas of the Atlantic Ocean (Mississippi Sound, Chesapeake Bay, Palmico Sound, Samborombón Bay and Mar Chiquita Lagoon) is difficult to explain. In relation to their morphological characters the two groups of monogeneans (from North and South Atlantic) are similar and impossible to differentiate. Thus the question remains of how this species could maintain the gene flow along all estuaries between the North and South Atlantic areas. A future molecular comparative study of this parasite from different populations could answer these last questions. New systematic studies on monogenean parasites of juvenile croakers, from different coastal areas, between the Gulf of Mexico and the Southwest Atlantic, could also help to explain this question.

\section{ACKNOWLEDGEMENTS}

We thank Robin Overstreet (Gulf, Coast Research Laboratory, University of Southern Mississippi) for loaning original specimens of $A$. bychowskyi for comparison. This study was supported by a grant from the Consejo Nacional de Investigaciones Científicas y Técnicas (CONICET).

\section{REFERENCES}

Acha E., Mianzán H., Lasta C., Guerrero R. 2001. Estuarine spawning of the whitemouth croaker, Micropogonias furnieri (Pisces: Sciaenidae), in the Rio de la Plata, Argentina. Marine and Freshwater Research 50: 57-65. 
Adams A.M. 1986. The parasite community on the gills of Fundulus kansae (Garman) from the South Platte River, Nebraska (USA). Acta Parasitologica Polonica 31: 47-54.

Alves D.R., Luque J.L. 1999. Aspectos quantitativos das infrapopulaçoes de metazoários parasitos de individuos jovens da corvina, Micropogonias furnieri (Osteichthyes: Sciaenidae) do litoral do Estado do Rio de Janeiro, Brasil. Contribuções Avulsas sobre a História Natural do Brasil, Série Zoologia 10: 1-4.

Alves D.R., Luque J.L. 2001. Community ecology of the metazoan parasites of white croaker, Micropogonias furnieri (Osteichthyes: Sciaenidae), from the coastal zone of the state of Rio de Janeiro, Brazil. Memorias do Instituto Oswaldo Cruz 96: 145-153.

Angelescu V., Prenski L.B. 1987. Ecología trófica de la merluza común (Merluccidae, Merluccius hubbsi). Parte 2. Dinámica de la alimentación analizada sobre la base de las condiciones ambientales, la estructura y las evaluaciones de los efectivos en su área de distribución. Contribuciones Instituto Nacional de Investigaciones y Desarrollo Pesquero Mar del Plata No. 561.

Arme C., Halton D.W. 1972. Observations on the occurrence of Diclidophora merlangi (Trematoda: Monogenea) on the gills of whiting, Gadus merlangus. Journal of Fish Biology 4: 27-32.

Buchmann K. 1989. Microhabitats of monogenean gill parasites on European eel (Anguilla anguilla). Folia Parasitologica 36: 321-329.

Bush A.O., Lafferty K.D., Lotz J.M., Shostak A.W. 1997. Parasitology meets ecology on its own terms: Margolis et al. revisited. Journal of Parasitology 83: 575-583.

Carozza C., Lasta C., Ruarte C., Cotrina C., Mianzán H., Acha M. 2004. Corvina rubia (Micropogonias furnieri). Pp. 255-270. In: Boschi E. (ed.) El Mar Argentino y sus recursos pesqueros. Los peces marinos de interés pesquero. Caracterización biológica y evaluación del estado de explotación. Publicaciones Especiales del Instituto Nacional de Investigación y Desarrollo Pesquero, Mar del Plata.

Etchegoin J.A., Sardella N. 1990. Some ecological aspects of the copepod parasites of the common hake, Merluccius hubbsi, from the Argentine-Uruguayan coasts. International Journal for Parasitology 20: 1009-1014.

Frankland H.M.T. 1955. The life history and bionomics of Diclidophora denticulata (Trematoda: Monogenea). Parasitology 45: 313-351.

Gutiérrez P.A., Martorelli S.R. 1994. Seasonality, distribution, and preference sites of Demidospermus valenciennesi (Monogenea: Ancyrocephalidae). Research and Reviews in Parasitology 54: 259-261.

Gutierrez P.A., Martorelli S.R. 1999a. Niche preferences and spatial distribution of Monogenea on the gills of Pimelodus maculatus in Río de la Plata (Argentina.) Parasitology 119: 183-188.

Gutierrez P.A., Martorelli S.R. 1999b. Hemibranch preference by freshwater monogeneans a function of gill area, water current, or both? Folia Parasitologica 46: 263-266.

Hanek G., Fernando C.H. 1978. Spatial distribution of gill parasites of Lepomis gibbosus (L.) and Ambloplites rupestris (Raf.). Canadian Journal of Zoology 56: 1235-1240.

Isaac-Nahum, V. J. 1988. Synopsis of biological data on the whitemouth croaker, Micropogonias furnieri (Desmarest, 1823). FAO Fisheries Synopsis 150. FAO, Rome.

Koskivaara M., Valtonen E.T., Vuori K.M. 1992. Microhabitat distribution and coexistence of Dactylogyrus species (Monogenea) on gills of roach. Parasitology 104: 273-281.

Lawler A.R., Overstreet R.M. 1976. Absonifibula bychowskyi gen. et sp. n. (Monogenea: Absonifibulinae subfam. n.) from the Atlantic croaker, Micropogon undulatus (L.), from Mississippi, U.S.A. Proceedings of the Institute of Biology and Pedology, Far-East Science Centre, Academy of Sciences of the USSR, New Series 34 (137): 83-91.

Llewellyn J. 1956. The host-specificity, micro-ecology, adhesive attitudes, and comparative morphology of some trematode gill parasites. Journal of Marine and Biological Association of the United Kingdom 35: 113-127.

López R.B., Castelo J.P. 1968. Corvinas del Río de La Plata. Boletín del Servicio de Hidrografía Naval 5: 14-27.

Morales G., Pino L. 1987. Parasitología Cuantitativa. Fundación Fondo Editorial Acta Científica Venezolana, Caracas.

Oliva M.E., Luque J.L. 1998. Distribution Patterns of Microcotyle nemadactylus (Monogenea) on Gill Filaments of Cheilodactylus variegatus (Teleostei). Memorias do Instituto Oswaldo Cruz 93: 477-478.

Rohde K. 1993. Ecology of marine parasites. 2nd edn. CAB International, Bristol, UK.

Rohde K., Roubal F. 1980. Ectoparasitic Monogenea, Digenea, and Copepoda from the gills of some marine fishes of New Caledonia and New Zealand. New Zealand Journal of Marine and Freshwater Research 14: 1-13.

Sardella N.H., Etchegoin J.A., Martorelli S.R. 1985. Las comunidades parasitarias de Micropogonias furnieri (corvina) en Argentina. Boletín del Instituto Oceanográfico de Venezuela. Universidad de Oriente 34: 41-47.

Sánchez F., Marí N., Lasta C., Giangiobbe A. 1991. Alimentación de la corvina rubia (Micropogonias furnieri) en la Bahía Samborombón. Publicación Comisión Técnica Mixta Frente Marítimo 8: 43-50.

Shotter R.A. 1973. Changes in the parasitic fauna of whiting Odontogadus merlangus L. with age and sex of host, season, and from different areas in the vicinity of the Isle of Man. Journal of Fish Biology 5: 559-573.

Suydam E.L. 1971. The micro-ecology of three species of monogenetic trematodes of fishes from the Beauford-Cape Hattereas area. Proceeding of the Helminthological Society of Washington 38: 240-246.

Thoney D.A. 1991. Population dynamics and community analysis of the parasite fauna of juvenile spot, Leiostomus xanthurus (Lacepede), and Atlantic croaker, Micropogonias undulatus (Linnaeus), (Sciaenidae) in two estuaries along the middle Atlantic coast of the United States. Journal of Fish Biology 39: 515-534.

Thoney D.A. 1993. Community ecology of the parasites of adult spot, Leiostomus xanthurus, and Atlantic croaker, Micropogonias undulatus (Sciaenidae) in the Cape Hatteras region. Journal of Fish Biology 43: 781-804.

Timi J.T., Lanfranchi A.L. 2006. Size relationships between the parasitic copepod, Lernanthropus cynoscicola, and its fish host, Cynoscion guatucupa. Parasitology 132: 207-213.

Vazzoler A.E.A. de M. 1991. Sintese de conhecimento sobre a biologia da corvina, Micropogonias furnieri (Desmarest, 1823), da costa do Brasil. Atlántica, Rio Grande 13: 55-74.

Received: 7 March 2007

Accepted: 9 May 2007

Published electronically: 15 July 2007 